Vol.2 No.2 Maret 2020

\title{
TINJAUAN HUKUM TERHADAP VIRUS KORONA, PEMECATAN PEGAWAI DAN KORUPSI
}

\author{
Ditulis Oleh:
}

Yida Sekti Purnomo, Pesmin Alvanis

\begin{abstract}
Pandemi korona kian menebar ancaman yang mengganggu stabilitas negara-negara yang ada di dunia. Indonesia termasuk yang kena dampak besar karena banyaknya warga negara Indonesia yang menjadi korban. Hal ini dapat berakibat pada timbulnya masalah serius yang menerpa paling setiap bidang kehidupan. Diantaranya yakni banyaknya perusahaan yang libur sebab ada larangan bekerja yang dibuat oleh pemerintah. Keadaan ini bisa "dimanfaatkan" oleh pengusaha yang kebetulan tidak suka dengan pegawai sehingga pegawai dipecat. Kalau ini terjadi, maka melanggar undang-undang bahkan pengusaha tersebut bisa dihukum seberat-beratnya karena melakukan tindakan tersebut pada saat sedang darurat. Keadaan darurat ini juga bisa digunakan oleh banyak pihak untuk melakukan kegiatan korupsi. Kenapa ini bisa terjadi? Karena pemerintah pusat Republik Indonesia telah membolehkan pemerintah daerah atau instansi untuk menggunakan sebagian dana dalam upaya melawan penyakit tersebut. oleh sebab itu menurut penulis situasi ini dapat dicegah ketika ada hukum khusus yang bisa memonitoring, mengevaluasi, memberi hukuman terhadap pemanfaatan keadaan seperti ini. Tentunya hukum khusus ini dibuat menurut hukum yang berlaku di negara Republik Indonesia yang kita cintai ini.
\end{abstract}

Kata Kunci: Korupsi, Pemecatan Pegawai, Virus.

DAFTAR PUSTAKA

Undang-Undang Nomor 19 Tahun 2019 tentang Perubahan Kedua Atas Undang-Undang Nomor 30 Tahun 2002 tentang Komisi Pemberantasan Tindak Pidana Korupsi.

Undang-Undang Republik Indonesia Nomor 24 Tahun 2011 tentang Badan Penyelenggara Jaminan Sosial.
Telaumbanua, Dalinama. 2020. "Restriktif Status Dewan Pengawas KPK." Jurnal Education and Development. vol. 8, no. 1

Telaumbanua, Dalinama. 2018. "Pembentukan Peraturan Daerah Kabupaten/Kota." Jurnal Education and Development. vol. 4, no. 1

Undang-Undang Nomor 17 Tahun 2003 tentang Keuangan Negara. 
Undang-Undang Republik Indonesia Nomor 40 Tahun 2004 tentang Sistem Jaminan Sosial Nasional.

Telaumbanua, Dalinama. 2019. "Kumpulan Undang-undang KPK Dalam Satu Naskah." LawArXiv. November 29. doi:10.31228/osf.io/ysju2.

Telaumbanua, Dalinama. 2020. "Urgensi Pembentukan Aturan Terkait Pencegahan Covid-19 Di Indonesia." QALAMUNA: Jurnal Pendidikan, Sosial, dan Agama. vol. 12, no. 1

Undang-Undang Nomor 13 tahun 2013 Tentang Ketenagakerjaan.

Undang-Undang Nomor 21 tahun 2000 Tentang Serikat Pekerja/Serikat Buruh.

Undang-Undang Nomor 31 Tahun 1999 tentang Pemberantas Tindak Pidana Koruksi.

Telaumbanua, Dalinama. 2019. Hukum Ketenagakerjaan. Deepublish.

Philipus M. Hadjon, 2010, Kontrak dengan Pemerintah ditinjau dari Sudut Pandang Hukum Asministrasi,Seminar Nasional Kontrak Kerja Jasa Konstruksi.

Widjaja, Gunawan, 2006. Tanggung Jawab Direksi Atas Kepailitan Perseroan. Jakarta: PT RajaGrafindo Persada. https://www.cnnindonesia.com/ekonomi/2 0200326075745-532-486933/hati- hati-dana-penanganan-wabahcorona-rawan-korupsi https://news.detik.com/berita/d4958994/ketua-dprd-dki-anggaranformula-e-bisa-untuk-penanganancorona https://katadata.co.id/berita/2020/03/30/ pemerintah-pusat-minta-daerahfokuskan-dak-fisik-untuk-tanganicorona

https://www.wartaekonomi.co.id/tag4606/ pemutusan-hubungan-kerja-phk https://www.cnbcindonesia.com/news/202 00327165713-4-148039/ganasnyacorona-hampir-100-kamar-hotel-dibali-kosong https://katadata.co.id/tags/phk-karyawan 